\title{
ОФИЦИАЛЬНЫЙ ОТДЕЛ
}

\section{Н А 3 Н А Ч Е Н И Я}

\author{
Полковник медицинской службы \\ ПАЦЕНКО МИХАИЛ БОРИСОВИЧ
}

назначен главным терапевтом Министерства обороны Российской Федерации,

\author{
полковник медицинской службы \\ ГНАШКО ОЛЕГ МИХАЙЛОВИЧ
}

назначен начальником медицинской службы Ракетных войск стратегического назначения,

\author{
полковник медицинской службы \\ ШУТОВ СЕРГЕЙ ВЛАДИМИРОВИЧ
}

назначен начальником медицинской службы Западного военного округа.

\section{И Т О ГИ К О Н К У Р С А}

Победителями финального этапа конкурса «Лучшая военно-медицинская организация 2018 года» признаны:

- 1-е место - Военно-медицинская академия имени С.М.Кирова (СанктПетербург);

- 2-е место - 1602-й Военный клинический госпиталь (Ростов-на-Дону);

- 3-е место - 52-й Консультативно-диагностический центр (Москва).

\section{Ю Б И Л Е И}

(C) А.В.ШАКУЛА, 2019

УДК 616:355 (092 Мельник С.Г.)

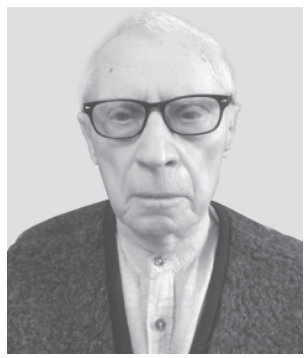

19 февраля 2019 г. исполнилось 90 лет участнику Великой Отечественной войны (1941-1945), кандидату медицинских наук полковнику медицинской службы в отставке Сергею Григорьевичу Мельнику.

С.Г.Мельник родился в с. Кутковцы Хмельницкой области УССР. В 1941-1944 гг. был разведчиком партизанского отряда им. В.И.Чапаева.

После окончания в 1955 г. ВМФ при Саратовском мединституте служил старшим врачом авиационного полка Дальней авиации. С 1961 по 1988 г. служил в Государственном научно-исследовательском испытательном институте авиационной и космической медицины, где прошел путь от младшего научного сотрудника до начальника лаборатории. В период 1964-1965 гг. С.Г.Мельник являлся военным советником в РВС Кубы.

Основными направлениями исследований С.Г.Мельника были психофизиологические особенности деятельности летного состава, разработка и внедрение организационно-методических принципов медицинской реабилитации в интересах сохранения летного долголетия. Он автор и соавтор более 200 научных работ.

Награжден орденом Отечественной войны II степени, многими медалями, почетной грамотой министра РВС Кубы.

Руководство Главного военно-медицинского управления Министерства обороны Российской Федерации и Научно-исследовательского испытательного центра авиационно-космической медицины и военной эргономики ЦНИИ ВВС, совет Объединения ветеранов военно-медицинской службы, редакционная коллегия «Военно-медицинского журнала» сердечно поздравляют Сергея Григорьевича Мельника с 90-летием и желают ему здоровья, благополучия и счастья. 
(С) И.А.КАЧУРОВСКИЙ, 2019

УДК 616:355 (092 Павленко Н.И.)

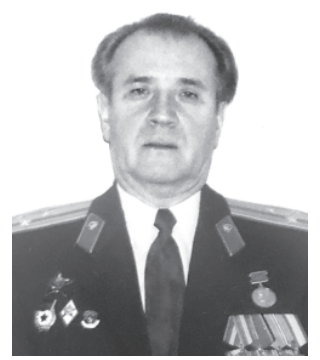

3 марта 2019 г. исполнилось 80 лет бывшему заместителю начальника медицинской службы Ракетных войск стратегического назначения полковнику медицинской службы в отставке Николаю Ивановичу Павленко.

Н.И.Павленко родился в г. Макеевке Донецкой области. После окончания Харьковского мединститута (1963) проходил службу в должности начальника полкового медпункта ракетного соединения. С 1971 г. служил в качестве старшего врача ракетного полка. В 1976 г. окончил с золотой медалью факультет подготовки руководящего медицинского состава ВМедА им. С.М.Кирова и был назначен начальником медицинской службы ракетного соединения РВСН. С 1979 по 1981 г. он являлся заместителем начальника медицинской службы объединения, а с 1981 г. руководил медицинской службой объединения РВСН.

В 1982 г. был назначен на должность заместителя начальника медицинской службы РВСН. В этот период оказывал эффективную практическую и методическую помощь медицинской службе воинских частей и учреждений Ракетных войск, являлся председателем центральной аттестационной комиссии медицинской службы РВСН и секретарем парткома Тыла РВСН.

После увольнения из ВС Николай Иванович с 1991 по 2000 г. плодотворно трудился в различных организациях Минобороны России. Он является кандидатом в мастера спорта по шахматам и волейболу.

Награжден орденом Красной Звезды, многими медалями, знаком «Отличник здравоохранения».

Руководство Главного военно-медицинского управления Министерства обороны Российской Федерации, медицинской службы Ракетных войск стратегического назначения, редакционная коллегия «Военно-медицинского журнала» сердечно поздравляют Николая Ивановича Павленко с юбилеем, желают ему здоровья, оптимизма и долгих лет жизни.

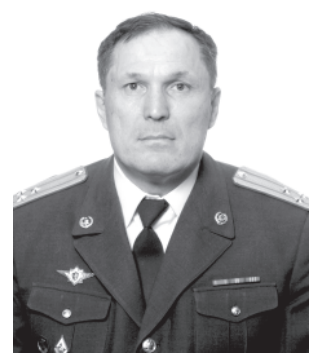

12 марта 2019 г. исполнилось 60 лет бывшему главному государственному санитарному врачу Космических войск полковнику медицинской службы запаса Геннадию Витальевичу Михееву.

Г.В.Михеев родился в д. Памашъял Марийской АССР. После окончания в 1982 г. Военно-медицинского факультета при Куйбышевском мединституте им. Д.И.Ульянова служил в должностях врача дивизиона гвардейского ракетного полка (1982-1983), врача-гигиениста санитарно-эпидемиологического отряда военного госпиталя ракетной дивизии (1983-1989). В 1989-2001 гг. он проходил службу старшим врачом-специалистом ЦСЭЛ РВСН.

С 2001 по 2010 г. Г.В.Михеев в должности главного государственного санитарного врача КВ внес большой вклад в решение актуальных проблем военной профилактической медицины.

После увольнения в запас Г.В.Михеев до настоящего времени продолжает трудиться в области профилактической медицины в качестве врача-эпидемиолога.

Награжден многими медалями и знаками отличия Минобороны России, РВСН, Космических войск.

Руководство Главного военно-медицинского управления Министерства обороны Российской Федерации, медицинской службы Ракетных войск стратегического назначения, медицинской службы Космических войск, редакционная коллегия «Военно-медицинского журнала» сердечно поздравляют Геннадия Витальевича Михеева с юбилеем, желают ему крепкого здоровья, благополучия и новых достижений. 
Руководство Главного военно-медицинского управления МО РФ, Военно-медицинской академии имени С.М.Кирова, друзья, сослуживцы и ученики с прискорбием извещают, что 21 февраля 2019 г. на 99-м году ушел из жизни участник Великой Отечественной войны, патриарх отечественной офтальмологии, создатель крупной научной школы, бывший начальник кафедры офтальмологии ВМедА и главный офтальмолог МО СССР (1967-1989), Герой Социалистического Труда, лауреат Государственной премии СССР, заслуженный деятель науки РСФСР, почетный академик РАЕН, кавалер 7 орденов и 25 медалей, профессор генерал-майор медицинской службы в отставке

\section{ВОЛКОВ Вениамин Васильевич}

и выражают соболезнование родным и близким покойного.

\section{Л ЕНТА НОВ О С ТЕ Й}

Начальник Главного военно-медицинского управления МО РФ Дмитрий Тришкин провел в Зале управления им. Г.К.Жукова Национального центра управления обороной $P \Phi$ селекторное совещание с руководящим составом медицинской службы Вооруженных Сил Российской Федерации.

В мероприятии участвовали начальники медицинских служб военных округов и флотов, руководители центральных военно-медицинских организаций.

Перед началом совещания был объявлен приказ начальника ГВМУ МО РФ в связи с Днем защитника Отечества, согласно которому за высокие показатели в служебной деятельности награжден ряд офицеров медицинской службы.

После вступительного слова начальника Главного военно-медицинского управления доклад по анализу заболеваемости и смертности военнослужащих Вооруженных Сил РФ от заболеваний в январе 2019 г. представил врио начальника 1 управления ГВМУ МО РФ полковник медицинской службы Сергей Сушильников.

Заболеваемость военнослужащих Западного военного округа в январе 2019 г. была проанализирована начальником медицинской службы 3ВО полковником медицинской службы Сергеем Шутовым.

Результаты использования доведенных лимитов бюджетных обязательств по итогам 2018 года, а также заключение контрактов в порядке, установленном постановлением Правительства Российской Федерации № 911, довел до участников совещания начальник 4 отдела 3 управления ГВМУ МО РФ Александр Мельник.

Об итогах работы по созданию региональных отделений организации ветеранов медицинской службы в военных округах, флотах, видах (родах) войск (сил) доложил доцент кафедры ОТМС Филиала Военно-медицинской академии имени С.М.Кирова (Москва) Игорь Корнюшко.

Итоги работы медицинских служб военных округов по оказанию медицинской помощи в январе 2019 г. подвели в своих выступлениях начальники медицинской службы Южного военного округа и Северного флота полковники медицинской службы Серго Папко и Юрий Закревский. Их выступления дополнили начальники медицинской службы Центрального и Восточного военных округов полковники медицинской службы Анатолий Калмыков и Арсалан Бальжинимаев.

Итоги совещания подвел в своем выступлении начальник ГВМУ МО РФ Дмитрий Тришкин, объявивший о новых назначениях по медицинской службе и поздравивший весь подчиненный состав с наступающим Днем защитника Отечества.

Воен.-мед. журн., 20 февраля 2019 г. 